INDEPENDENT JOURNAL OF MANAGEMENT \& PRODUCTION (IJM\&P)

http://www.ijmp.jor.br

v. 10, n. 2, March - April 2019

ISSN: 2236-269X

DOI: 10.14807/ijmp.v10i2.842

\title{
STUDY OF TIMES AND MOVEMENTS IN THE SERVICE SECTOR: AN ANALYSIS IN A BEAUTY SALON
}

\author{
Jéssica Danielle de Carvalho Nunes \\ Federal Rural University of the Semi-Arid, Mossoró/RN, Brazil \\ E-mail: jdcnunes@gmail.com \\ Ana Maria Magalhães Correia \\ Federal Rural University of the Semi-Arid, Mossoró/RN, Brazil \\ E-mail: anamagalhaes@ufersa.edu.br \\ Priscila Gonçalves Vasconcelos Sampaio \\ Federal Rural University of the Semi-Arid, Mossoró/RN, Brazil \\ E-mail: priscila.sampaio@ufersa.edu.br \\ Alexandre Henrique Soares de Oliveira \\ Federal Rural University of the Semi-Arid, Mossoró/RN, Brazil \\ E-mail: alexandrehso@gmail.com \\ Armistrong Martins da Silva \\ Federal University of Paraíba, Bananeiras/PB, Brazil \\ E-mail: armistrongmartins@gmail.com
}

Submission: 01/06/2018

Revision: 15/06/2018

Accept: 21/09/2018

\section{ABSTRACT}

This work presents a review of motion and time made in the most performed service in a small beauty salon in Mossoró - RN - Brazil. Thus, this research aims to use the knowledge derived from the engineering of methods, precisely, the studies movements and times and to associate such studies, which were developed mainly within the manufacturing process, to bring to a service delivery environment. To have specific objectives, to prepare a flowchart of the operation of the manicure service, to find the standard time of this service through the chronoanalysis of the stages of the task and to carry out the study of the methods developed during the execution of the service in question. In this sense, it can conclude that employing the chrono-analysis tool, the default time for the chosen operation is approximately 36 minutes. 
INDEPENDENT JOURNAL OF MANAGEMENT \& PRODUCTION (IJM\&P)

http://www.ijmp.jor.br

v. 10, n. 2, March - April 2019

ISSN: 2236-269X

DOI: 10.14807/ijmp.v10i2.842

This finding means that this is the period required to provide a unit of the manicure service, considering the skills, efforts, conditions, and consistencies of the operator, the physical environment, the materials, and equipment analyzed. This work presents a study of motion and time in the most performed service in a small beauty salon in the city of Mossoró/RN, in Brazil.

Keywords: time study, movements, service sector, beauty salon, production

\section{INTRODUCTION}

Developing studies on service delivery has been one of the challenges for researchers in this area. According to Corrêa and Gianese (2012), the management of operations has undergone profound changes in recent years due to the new standards of competition in the world market. For Lovelock, Wirtz and Hemzo (2011) services are economic activities offered by one party to another, often considering performance based on a period to bring about desired outcomes on the users themselves, objects or other goods for which buyers are responsible. In this same context, Fitzsimmons and Fitzsimmons (2010) add that many definitions of services found, but all consider the intangibility and the simultaneous consumption, to different degrees, as characteristics of the services.

Miao et al. (2012) use Servqual to analyze mainly, the Technical Quality, Company Image and functional quality of services provided, serving as a link between customer participation and customer value, thus, from the use of Servqual is possible to evaluate the gaps between the expectation and the reality of the service provided, from a customer perspective. Talluri, Kim, and Schoenherr (2013) also highlight the use of Servqual as one of the prerogatives for evaluating the relationship between efficient operation and Service Quality.

The annual growth of services according to the quarterly national of the Brazilian Institute of Geography and Statistics (IBGE) shows that the service sector (which encompasses commerce) from 2003 to 2013 went from 64.7\% to 69, 4\%) of the added value of the GDP. Since 2004, services have been gaining ground in GDP. In particular, trade shows a significant expansion, from (10.6\%) in 2003 to $(12.7 \%)$ the value added of the GDP in 2013. The importance of this activity in our society can be demonstrated both by the position occupies the economy as regards the contribution of the Gross Domestic Product and the generation of jobs, as well as 
INDEPENDENT JOURNAL OF MANAGEMENT \& PRODUCTION (IJM\&P)

http://www.ijmp.jor.br

v. 10, n. 2, March - April 2019

ISSN: 2236-269X

DOI: 10.14807/ijmp.v10i2.842

the analysis of the trends and transformations that the world economy is experiencing (CORRÊA; GIANESE, 2012).

In this paper, we will show that in Brazil, services are responsible for $60 \%$ of the generation of wealth in the national economy. And this is associated with factors such as: (i) a desire for a better quality of life and more leisure time; (ii) urbanization, making specific services necessary (such as security); (iii) demographic changes that increase the number of children and / or elders, who consume a greater variety of services; (iv) socioeconomic changes such as increased participation of women in paid work and pressures on personal time; (v) increasing consumer sophistication, leading to broader service needs; (vi) technological changes (such as the advancement of computers and telecommunications) that have improved the quality of services, or even created entirely new services.

Given the above, within the classified category of other services, an area that encompasses all service sectors that do not fit into the different classifications. And in the type of services whose nature deals with tangible actions and directed to the body of the people have the service of personal care, developed in service factories more known explicitly as beauty salons. The Brazilian beauty market is the fourth largest in the world in this sector, after the United States, Japan, and China. This economic sector in Brazil represents $1.8 \%$ of Gross Domestic Product (GDP) in 2015. Moreover, this productive activity maintained a relevant growth despite the economic downturn of the country. Personal cares and beauty are cultural characteristics of Brazilians, this factor corroborates to the sustainable growth of this economic area (WEINSWIG 2016).

According to Brazilian Service to Support Micro and Small Enterprises (2016), the beauty salon business offers services aimed at hair aesthetics, hygiene, aesthetics and beautification of the hands and feet, hair removal, aesthetics of eyebrows and eyelashes, facial makeup, and other aesthetic services facial and body. It is a business that requires high-level professional performance and in tune with the trends defined by world standards since the ease of communication has definitively broken local barriers. Therefore, technical or higher-level vocational courses emerge every day, creating new standards of performance and specializing the services 
INDEPENDENT JOURNAL OF MANAGEMENT \& PRODUCTION (IJM\&P)

http://www.ijmp.jor.br

v. 10, n. 2, March - April 2019

ISSN: 2236-269X

DOI: 10.14807/ijmp.v10i2.842

Thus, in the segment of services offered by beauty salons, due to the increase in the sophistication of consumers, the diversity of the activities provided and the intense competition, there is a need to establish a lasting relationship with the client (NORONHA; OLIVEIRA; LEITE, 2006). So that to make customers loyal to the company, to avoid migrating to the competitor in search of better conditions of service, price, and quality of service, it is essential that the experience of the professional that will provide the service linked to its maximum degree of productivity.

Since according to Juran and Gryna (1993) the fulfillment of deadlines and shorter time in the execution of the service are competitive factors. In this perspective, Pollack (2008) brings an analysis of beauty salon services together with other two types of services (banking and telephone). And in this evaluation of the relationship between satisfaction and quality, the author identified as critical attributes those who have a relatively more significant influence in the perceived quality and present a linear relationship with pleasure and concludes that waiting time is one of the critical factors.

In this perspective, it is relevant to bring to light studies that seek to optimize both the waiting time and the time of execution of the services offered by a beauty salon. In this way, a tool that can be used to deal with this problem linked to Method Engineering, which according to Souto (2004) consists of the technique that is directly concerned with the implementation of methods and the workload analysis, with the work income and to suppress any unnecessary operation of a task.

Includes in this context the study of movements and times, according to Barnes (1977) is the organized study of work processes that aims to develop the system and the preferred method, usually the one of lower cost; standardize this system and method; determine the time spent by a qualified, trained person working at an average pace to perform a specific task or operation and guide the training of the operator in the preferred method. All of which is primarily concerned with determining the ideal or closest approach to be used in practice.

Thus, in production systems, where the use of labor is abundant, and in the case, in question, that deals with services available in a beauty salon. Whose use of work is constant; it is essential to develop a study of designates as being the 
INDEPENDENT JOURNAL OF MANAGEMENT \& PRODUCTION (IJM\&P)

http://www.ijmp.jor.br

v. 10, n. 2, March - April 2019

ISSN: 2236-269X

DOI: 10.14807/ijmp.v10i2.842

maximum quantity of products and services that produced in a productive unit in a given interval of time.

In this sense, there is relevance to the science of production engineering, by contributing to establish standards for production schedules, providing data for the determination of standard time, as well as for the study of balance of production structures. So, the implementation of methods and work engineering becomes essential for an organization, since its techniques propose to identify and suggest modifications to improve the current working method.

This time, the present work aims to use the knowledge from the engineering of methods, precisely, the studies motion and time and to associate such studies, which were developed mainly within the manufacturing process, and bring to a service delivery environment. With specific objectives, to elaborate a flowchart of the manicure process, to find the standard time of the service through the chronoanalysis of the stages of the task and to carry out the study of the methods developed during the execution of the service in question.

\section{STUDY OF TIMES AND MOVEMENTS}

According to Contador (2010), the first applications of the study of times date from the nineteenth century, coming from the contributions of Frederick Taylor to determine the time needed to perform the various types of work and projections correctly to implement them. Thus, Tardin et al. (2013) add that the time study eliminates any unnecessary elements and determines the best and most efficient method to perform a task. In this sense, in the view of Slack, Chambers, and Johnston (2009), the study of times, or measurement of work, is the application of established techniques to determine the time necessary for a skilled and specified worker to perform the task in a defined level of performance. Therefore, this time called the standard operation time.

Given the above, it is possible to deal with techniques for determining the standard time, among which timing, according to Contador (2010) is one of the most usual methods of observation. And for execution of the same it is necessary a centesimal chronometer, clipboard, and sheet and for this author should follow the steps listed below:

- Obtain information about the operation and operator under study; 
- Divide the process into elements and record the complete description of the method;

- Observe and record the time spent by the operator;

- Determine the number of cycles to be timed;

- Evaluate the pace of the operator;

- Determine the normal time;

- Determine the tolerances;

- Determine the standard operation time.

For Barnes $(1977,284 . p)$ the higher the number of timed cycles the more representative the results obtained for the study activity, so the number of observations (cycles) will depend on the precision desired for that element of study. According to Moreira (2009) as a rule, the number of cycles can be adjusted by the analyst's common sense, until feels confident in the results found or by statistical means. Barnes (1977) claims that is necessary to realize the calculation by equation (1), in which $N^{\prime}$ is the number of observations required to predict the true time with relative error of $\pm 5 \%$ and $95 \%$ confidence, in which the $X$ is the chronometer reading and $\mathrm{N}$, the number of observations from the preliminary study.

$$
N^{\prime}=\left(\frac{40 \sqrt{N \sum X^{2}-\left(\sum X\right)^{2}}}{\sum X}\right)^{2}
$$

Barnes (1977) explains the evaluate the pace of the operator as the process during which the time-study analyst compares the rhythm of the observing operator to his concept of normal rhythm. According to the above-mentioned author, it is a four-factor system for estimating operator efficiency and was developed at Westinghouse in 1927.

In order to meet the standard time and consequently the operator's pace, the Westinghouse System was used, in which the four factors are: (a) ability: which is the competence to follow a method, (b) effort: which is associated with a constant rhythm during an operation, (c) conditions: related to the environment, machines, 
INDEPENDENT JOURNAL OF MANAGEMENT \& PRODUCTION (IJM\&P)

http://www.ijmp.jor.br

v. 10, n. 2, March - April 2019

ISSN: 2236-269X

DOI: 10.14807/ijmp.v10i2.842

tools, and others, and (d) consistency of the movements, to estimate the efficiency of the work, according to the performance estimation of the Table 1 :

Table 1: Performance estimation table

\begin{tabular}{|c|c|c|c|c|c|}
\hline \multicolumn{3}{|c|}{ Ability } & \multicolumn{3}{|c|}{ Effort } \\
\hline 0.15 & $\mathrm{~A} 1$ & Super-skilled & 0.13 & A1 & Excessive \\
\hline 0.13 & $\mathrm{~A} 2$ & & 0.12 & A2 & \\
\hline 0.11 & B1 & Excellent & 0.10 & B1 & Excellent \\
\hline 0.08 & $\begin{array}{l}\text { B2 } \\
\text { C }\end{array}$ & & 0.08 & $\begin{array}{l}\text { B2 } \\
\text { C }\end{array}$ & \\
\hline $\begin{array}{l}0.06 \\
0.03\end{array}$ & $\begin{array}{l}1 \\
C \\
2\end{array}$ & Good & $\begin{array}{l}0.05 \\
0.02\end{array}$ & $\begin{array}{l}1 \\
C \\
2\end{array}$ & Good \\
\hline 0.000 & $\mathrm{D}$ & Middle & 0.00 & $\mathrm{D}$ & Middle \\
\hline-0.05 & E1 & Regular & -0.04 & E1 & Regular \\
\hline-0.10 & E2 & & -0.08 & E2 & \\
\hline-0.16 & F1 & Low & -0.12 & $\mathrm{~F} 1$ & Low \\
\hline-0.22 & $\mathrm{~F} 2$ & & -0.17 & $\mathrm{~F} 2$ & \\
\hline \multicolumn{3}{|c|}{ Conditions } & \multicolumn{3}{|c|}{ Consistency } \\
\hline 0.06 & A & Ideal & 0.04 & $A$ & Perfect \\
\hline 0.04 & B & Excellent & 0.03 & B & Excellent \\
\hline 0.02 & C & Goof & 0.01 & C & Good \\
\hline 0.00 & D & Middle & 0.00 & D & Middle \\
\hline-0.03 & $E$ & Regular & -0.02 & E & Regular \\
\hline-0.07 & $\mathrm{~F}$ & Low & -0.04 & $\mathrm{~F}$ & Low \\
\hline
\end{tabular}

Considering this, Souto (2004) determines the operator's pace per hour in the Equation 2:

$$
\text { Pace }=100+\text { Ability }+ \text { Effort }+ \text { Conditions }+ \text { Consistency }
$$

According to Barnes (1977), normal time is the time that a qualified and trained operator takes to complete a duty cycle working at a normal pace. To calculate the normal time, Equation 3 is used, in which $S T$ is the selected time and $P$ is the operator's pace (speed of the operation).

$$
N T=S T \times P
$$

The tolerance (Equation 3) is a prediction of work slack for the workers rest and meeting their personal needs (BARNES, 1977; MARTINS; LAUGENI, 2005). There is an estimate for light work, with a workload of 8 hours per day, the average worker will have 10 to 24 minutes per day for personal time. For heavy work and 
occurring under unfavorable conditions, such as in hot and humid atmosphere, the average worker will have a longer tolerance time, which may be longer than 24 minutes (BARNES, 1977).

The standard time (Equation 4) is the duration of all elements of the operation and must include the time for all necessary tolerances (BARNES, 1977).

$$
S T=N T+(N T \times T o l)
$$

Consider in equation:

- $\mathrm{ST}=$ Standard Time;

- NT = Normal Time;

- $\quad$ Tol $=$ Tolerance

Anis (2010) explains that as a result of the chronoanalysis the standard time is searched and Souto (2004) describes that this standard time can be used for several purposes, such as scheduling and planning work, determining costs standard, estimate the cost of a product before beginning manufacturing, establish bases for wage incentive plans, and control the cost of labor. However, Toledo Júnior (2004) elucidates that the standard time viewed in an individualized way has little or no value since it is only a mechanical act.

While Taylor was primarily concerned with the study of the times, one of his disciples, Frank B. Gilbreth (1868-1924), expanded his time studies to what he called the study of movements. Helped by his wife, the psychologist Lilian M. Gilbreth, they were complemented to perfect their work on the study of motion (VIEIRA, et al. 2015).

According to the authors cited, the Gilbreth couple encouraged the study of micromovements, identifying that any task in industrial production can be divided into primary movements, among them: searching, picking, picking up, transporting empty, transporting full, prepositioning, positioning, unite, separate, use, drop load, inspect, hold, wait, stand and plan.

According to Felippe, et al. (2012), Gilbreth subdivided Taylor's elements into basic movements that he called therbligs (set of basic moves necessary for the worker to perform operations on manual tasks). And in this same reasoning, Borba 
DOI: 10.14807/ijmp.v10i2.842

et al. (2008) explain that these therbligs were used to establish the standard time of operation as Taylor did with its elements.

Thus, for Vieira, et al. (2015), the use of schematic resources in the study of methods has provided an efficient survey of the process analysis to achieve improvements. In this same context, Santos, Barreto, and Menezes (1998) point out that these schemes allow the correction of errors when detected and designate patterns to be recognized more easily.

Among the various schematic features present in the methods engineering studies, the flowchart or flowchart of the process are a technique to register a process in a compressed way, to obtain possible its better understanding and improvement (BARNES, 1977).

In this way, the Process Flow Chart, more commonly called a flowchart, records exclusively fixed and constant sequences of a work and its purpose is to represent the production process through the series of transformation, examination, manipulation, movement, and storage activities by which pass the production item flows or the sequence of actions, waits and movements inherent provision of specific service. Therefore, the symbology used in the graphic representation is shown in the Table 2:

Table 2: Symbology of the flow chart of processes used for industrial processes

\begin{tabular}{|c|c|c|}
\hline Symbol & Description & Example \\
\hline & $\begin{array}{l}\text { Operation: Occurs when } \\
\text { modifying an object in any of } \\
\text { its physical or chemical } \\
\text { characteristics }\end{array}$ & $\begin{array}{l}\text { Hammer a nail, put a screw, } \\
\text { rivet, bend, type, fill out a form, } \\
\text { write, mix, connect and operate } \\
\text { a machine, etc. }\end{array}$ \\
\hline & $\begin{array}{l}\text { Transport: Occurs when an } \\
\text { object or raw material is } \\
\text { transferred from one place to } \\
\text { another. }\end{array}$ & $\begin{array}{l}\text { Carry manually or with a cart, } \\
\text { using a conveyor, carry the } \\
\text { load of a truck, carry a } \\
\text { document from one sector to } \\
\text { another, etc. }\end{array}$ \\
\hline & $\begin{array}{l}\text { Wait or Delay: Occurs when } \\
\text { an object or raw material } \\
\text { remains to wait for } \\
\text { processing or forwarding. }\end{array}$ & $\begin{array}{l}\text { Wait for transportation, } \\
\text { inventories in process awaiting } \\
\text { material or processing, papers } \\
\text { waiting for a signature, etc. }\end{array}$ \\
\hline & $\begin{array}{ll}\text { Inspection: Occurs when an } \\
\text { object or raw material is } \\
\text { examined for } & \text { its } \\
\text { identification, quantity } & \text { or } \\
\text { condition of quality. } & \end{array}$ & $\begin{array}{l}\text { Measure product dimensions, } \\
\text { check screwdriver pressure or } \\
\text { torque, check the quantity of } \\
\text { material, check load, etc. }\end{array}$ \\
\hline & $\begin{array}{l}\text { Storage: Occurs when an } \\
\text { object or raw material is kept } \\
\text { in a specific protected area in } \\
\text { the form of stock. }\end{array}$ & $\begin{array}{l}\text { Maintain raw material in the } \\
\text { warehouse, finished product in } \\
\text { stock, archived documents, } \\
\text { computer files, etc. }\end{array}$ \\
\hline
\end{tabular}

Source: Peinado e Graeml (2007). 
INDEPENDENT JOURNAL OF MANAGEMENT \& PRODUCTION (IJM\&P)

http://www.ijmp.jor.br

v. 10, n. 2, March - April 2019

ISSN: 2236-269X

DOI: 10.14807/ijmp.v10i2.842

The process flowchart is a method used to register a process in detail, seeking to make possible its better understanding and subsequent improvement. In this sense, this technique is a visual resource where the company's management uses to analyze productive systems, seeking to identify opportunities to improve the efficiency of processes since such improvements can be found with a detailed study of this graph, that it is common to conclude that certain operations may be eliminated, reduced or combined, contributing to the production of a better product or service at a lower cost (BARNES, 1977; PEINADO; GRAEML, 2007).

\section{METHODOLOGY}

This research is characterized, as to its nature, as being applied, since it aims to generate knowledge, for practical application, directed to the solution of problems related to the provision of the service performed by the manicure. The choice of this service was due to the fact that, among the various services provided in the beauty salon, the manicure service is considered the most frequent service (30\%).

The methodological course in this work is detailed through data collection and analysis. The quantitative approach is emphasized in the measures related to the times involved in executing the task execution; while the qualitative approach is used in the observations made about the methods and tools used. Regarding the objectives, it is noticed that in the visits made to the company for knowledge of its facilities and data collection, the research characterizes itself as being descriptive.

However, in the conversations with employees to better understand the process in question and through literature review, the research has an exploratory character. Regarding the technical procedures, it is considered a case study, since it consists of an in-depth study of the provision of the service in question, so that its ample and detailed knowledge is allowed.

The research was developed in four stages. The first step was to review the literature on the study of times and movements for a better understanding of the theme. The second stage included the data collection, which was carried out in loco during a week, according to the schedules previously scheduled by the clients. Data collection involved the use of the following instruments: chronometer (to measure the activity time); check sheet (to record collected data); camera and camcorder (to record images and videos of task execution and environment). At this stage it was 
possible to know the functioning of the salon, its facilities, observe the whole process involving the manicure service. During the observation periods, there were no interventions in the process by the researcher, since the objective of the observation was only to know and register the stages of execution of the tasks.

The third step consisted in the data analysis, which involved the construction of the flow chart, as well as the determination of the standard time through the chronoanalysis. The chronoanalysis comprised in division the process into elements, observe and record the time spent by the manicure, determine the number of cycles to be timed, evaluation the rhythm of the manicure and determine the normal time, as well as the tolerances and the standard time of the operation. In the fourth step it was possible to point out improvement suggestions to optimize both the standard time and the developed method.

\section{RESULTS AND DISCUSSION}

This section is divided into: (1) flowchart of the manicure service process, which begins with the client's arrival at the beauty salon and ends with the application of spray for rapid enamel drying and (2) chronoanalysis and suggestion of improvements for a better provision of the service.

\subsection{Flow chart of the process applied in the current method of the manicure service provision}

The process flow graph is concerned with recording only fixed and constant sequences of work. Its primary purpose is to represent the production process through the series of transformation, examination, manipulation, movement and storage activities through which production item flows. Therefore, the first phase of the present work was done with the elaboration of the flow diagram of the manicure service process and the same was detailed with the symbols corresponding to each action of the process, according shown to Table 3.

Table 3: Flowchart of the analyzed operation

\begin{tabular}{|c|c|c|c|}
\hline Stage $\mathbf{N}^{\circ}$ & Process Steps & Action Performer & Type of activity \\
\hline $\mathbf{1}$ & Beauty salon arrival & Costumer & $\supset \Rightarrow \square \square \nabla$ \\
\hline $\mathbf{2}$ & $\begin{array}{c}\text { Choose the color of the nail } \\
\text { polish on the shelf }\end{array}$ & Costumer & $\bigcirc \Rightarrow \square \square \nabla$ \\
\hline $\mathbf{3}$ & Go to the armchair & Costumer & $\bigcirc \square \square \nabla \diamond$ \\
\hline $\mathbf{4}$ & $\begin{array}{c}\text { Accommodation in the } \\
\text { armchair }\end{array}$ & Costumer & $\bigcirc \Rightarrow \mathbf{D} \square \nabla \nabla$ \\
\hline
\end{tabular}


INDEPENDENT JOURNAL OF MANAGEMENT \& PRODUCTION (IJM\&P)

http://www.ijmp.jor.br

v. 10, n. 2, March - April 2019

ISSN: 2236-269X

DOI: 10.14807/ijmp.v10i2.842

\begin{tabular}{|c|c|c|c|}
\hline 5 & $\begin{array}{l}\text { Visual inspection of hands } \\
\text { and nails }\end{array}$ & Customer/Operator & $\ominus \triangleright \square \nabla \diamond$ \\
\hline 6 & Check for nail polish & Operator & $\bigcirc \Rightarrow \square \nabla$ \\
\hline 7 & Yes: remove the nail polish & Operator & $\Rightarrow \square \square \nabla \diamond$ \\
\hline 8 & Do not: clean the nail & Operator & $\Rightarrow \square \square \nabla \diamond$ \\
\hline 9 & Get the scissors & Operator & $\bigcirc \rightarrow \square \nabla \diamond$ \\
\hline 10 & Cut the nails & Operator & $\Rightarrow \square \square \nabla \diamond$ \\
\hline 11 & Store the scissors & Operator & $\bigcirc \square \square \nabla \diamond$ \\
\hline 12 & Take the nail file & Operator & $\bigcirc \rightarrow \square \nabla \diamond$ \\
\hline 13 & Sanding nails & Operator & $\Rightarrow \square \square \nabla \diamond$ \\
\hline 14 & Discard used sandpaper & Operator & $\circ \Rightarrow \square \nabla \diamond$ \\
\hline 15 & $\begin{array}{l}\text { Surface clean nails and } \\
\text { hands }\end{array}$ & Operator & $\bullet \triangleright \square \nabla \diamond$ \\
\hline 16 & Pass the cuticle emollient & Operator & $\mathbf{0} \Rightarrow \square \square \nabla<$ \\
\hline 17 & $\begin{array}{l}\text { Diffuse moisturizing cream on } \\
\text { hands }\end{array}$ & Operator & $\bullet \square \square \nabla \diamond$ \\
\hline 18 & Coat every hand with a glove & Operator & $\Leftrightarrow D \square \nabla \diamond$ \\
\hline 19 & $\begin{array}{c}\text { Wait a moment for the } \\
\text { emollient and the moisturizer } \\
\text { to act. }\end{array}$ & Operator & $\circ \Rightarrow \mathbf{D} \square \nabla<$ \\
\hline 20 & Cut the tip of the glove finger & Operator & $\Leftrightarrow \square \square \nabla \diamond$ \\
\hline 21 & Pick up nail cutters & Operator & $\bigcirc \Rightarrow \square \nabla \Delta$ \\
\hline 22 & Position in right hand & Operator & $\Rightarrow \square \square \nabla \diamond$ \\
\hline 23 & $\begin{array}{l}\text { Support the client's finger in } \\
\text { the proper position }\end{array}$ & Operator & $\Leftrightarrow \square \square \nabla \diamond$ \\
\hline 24 & $\begin{array}{c}\text { Starts removing cuticle } \\
\text { process }\end{array}$ & Operator & $\bullet \Rightarrow \square \nabla<$ \\
\hline 25 & Cleans nails and hands & Operator & $\Rightarrow \square \square \nabla \diamond$ \\
\hline 26 & Wipe fingernails and hands & Operator & $\Rightarrow \square \square \nabla \diamond$ \\
\hline 27 & Pass base coat on the nail & Operator & $\Leftrightarrow \square \square \nabla \diamond$ \\
\hline 28 & $\begin{array}{l}\text { Continue painting the nails } \\
\text { with the product chosen by } \\
\text { the customer }\end{array}$ & Operator & $\Rightarrow \square \square \nabla$ \\
\hline 29 & $\begin{array}{l}\text { Paint second coat of nail } \\
\text { polish }\end{array}$ & Operator & $\mathbf{0} \Rightarrow \square \square \nabla \diamond$ \\
\hline 30 & $\begin{array}{l}\text { Make the detail at the tip of } \\
\text { the nail (frieze) }\end{array}$ & Operator & $\vec{\bullet} \Rightarrow \square \square \nabla \diamond$ \\
\hline 31 & Get the toothpick & Operator & $\bigcirc \Rightarrow \square \nabla \nabla$ \\
\hline 32 & $\begin{array}{l}\text { It involves the tip of the } \\
\text { toothpick with cotton }\end{array}$ & Operator & $\bullet \bullet \square \nabla \diamond$ \\
\hline 33 & Take the acetone glass & Operator & $\mapsto D \square \nabla \diamond$ \\
\hline 34 & $\begin{array}{l}\text { Wet cotton from the tip of the } \\
\text { toothpick }\end{array}$ & Operator & $\Rightarrow \triangleright \square \nabla \diamond$ \\
\hline 35 & Store acetone & Operator & $\bigcirc \rightarrow \square \nabla \diamond$ \\
\hline 36 & Cleans excess of nail polish & Operator & $\Leftrightarrow \square \square \nabla \diamond$ \\
\hline 37 & Discard the toothpick & Operator & $\Rightarrow \triangleright \square \nabla \diamond$ \\
\hline 38 & $\begin{array}{c}\text { Pick up nail polish fixation } \\
\text { spray }\end{array}$ & Operator & $\ominus \square \square \nabla \diamond$ \\
\hline 39 & Apply the spray & Operator & $\overrightarrow{0} \Rightarrow \square \nabla \diamond$ \\
\hline 40 & $\begin{array}{l}\text { Repeat this process on all } \\
\text { fingernails }\end{array}$ & Operator & $\bullet \triangleright \square \nabla \diamond$ \\
\hline
\end{tabular}

Source: Prepared by the author with research data 


\subsection{Chronoanalysis}

The application of the chronoanalysis initially consisted of the: (a) division of the operation into elements and complete recording of the method; followed by the (b) observation and recording of the time spent by the manicure; (c) determination of the number of cycles to be timed and evaluation of the rhythm of the manicure, were sufficient; (d) determination of the tolerances, and finally the (e) determination of the standard time.

\subsubsection{Division of operation in elements}

The process of service delivery chosen to perform the time study was divided into five elements to obtain a better description of the method. In this way, the items distributed as follows:

- 1st element: consists of the client's entrance into the physical environment and its orientation and accommodation to the specific place where it will receive the service and the choice of the color of the nail polish to be used (Step 1 to step 4);

- 2nd element: it covers the beginning of the process, goes from the visual inspection to an analysis of the nail that will transform the interactions between the operator and the client for making decisions regarding dimensions of the cut, sandpaper and the color of the nail polish that will be used (Step 5 to step 15);

- 3rd element: it includes the preparation of the nail, hydration of the hands, removal of cuticles and cleaning and preparation for painting (Step 16 to step 26);

- 4th element: it consists of the steps of painting the nail, initially with a transparent base coat and then the two layers with nail polish chosen at the time of entry (Step 27 to step 30);

- 5th element: refers to the cleaning process, application of the fixing spray and final finishes (Step 31 to step 40);

After the division of the operation completed in elements pointing to its proper description, it was observed and recorded the times spent in the development of each of these elements. 
INDEPENDENT JOURNAL OF MANAGEMENT \& PRODUCTION (IJM\&P)

http://www.ijmp.jor.br

v. 10, n. 2, March - April 2019

ISSN: 2236-269X

DOI: 10.14807/ijmp.v10i2.842

\subsubsection{Observation and registration of time by the operator}

According to the division of the stages and constitution of the elements that make up the provision of the service, the complete description of the records of the times spent in each element is presented in Table 4.

Table 4: Records of the times spent in each element

\begin{tabular}{|l|c|c|c|c|c|c|}
\hline \multicolumn{1}{|c|}{ Description of Element } & \multicolumn{5}{|c|}{ Number of observations } & \multirow{2}{*}{ Aver.Time } \\
\cline { 2 - 7 } & $\mathbf{1}$ & $\mathbf{2}$ & $\mathbf{3}$ & $\mathbf{4}$ & $\mathbf{5}$ & 138.8 \\
\hline $\begin{array}{l}\text { 1st element: client entry in the } \\
\text { environment and choose the color } \\
\text { of the nail polish to be used. }\end{array}$ & 120 & 150 & 137 & 165 & 122 & 164.0 \\
\hline $\begin{array}{l}\text { 2nd element: process start (cut, } \\
\text { sandpaper and nail polish color to } \\
\text { be used) }\end{array}$ & 172 & 150 & 117 & 181 & 200 & \\
\hline $\begin{array}{l}\text { 3rd element: it includes nail } \\
\text { preparation, hydration of the } \\
\text { hands, removal of the cuticles and } \\
\text { cleaning and preparation for } \\
\text { painting. }\end{array}$ & 376 & 420 & 356 & 466 & 627 & 449.0 \\
\hline $\begin{array}{l}\text { 4th element: nail Painting Steps } \\
\text { 5th element: the cleaning } \\
\text { process, application of the fixing } \\
\text { spray and final finishes. }\end{array}$ & 266 & 502 & 253 & 558 & 562 & 428.2 \\
\hline \multicolumn{2}{|c|}{1230} & 1543 & 1256 & 1801 & 1879 & \\
\hline
\end{tabular}

Source: Prepared by the author with research data

The time recording of each element was done using the timing technique, that according to Table 4, 5 initial timings were performed for each element of the operation, obtaining as average time for elements 1, 2, 3, 4 and 5, that correspond to 138.8 seconds, 164 seconds, 449 seconds, 361.8 seconds, 428.2 seconds respectively. The total time of operation was 1541.8 seconds.

The timings were carried out for one week according to the schedules scheduled by the clients. About this, Figueiredo, Oliveira and Santos (2011) affirm that the use of this tool can determine the most efficient and fast method to execute an operation, also having the possible identification of failures and reduction of product costs, since it is known that the second Juran and Gryna (1993) Compliance with deadlines and shorter time in the execution of the service are competitive factors. Another relevant factor is the question raised by the research by Ribeiro, Thisen, and Tinoco (2013) that pointed out among the three primary attributes of the perceived quality of the beauty salon service the commitment to the scheduled time, which depends directly on time spent in the development stages of the service. 


\subsubsection{Determination of the number of cycles to be timed or sampling of work}

Throughout the one-week period, 5 (five) preliminary timings of the entire process were chosen for to realize the time study. The total time of each of the 5 (five) observations were used to calculate the number of cycles to be timed (Equation 1), corresponding to a confidence level of (95\%) with a relative error of \pm $5 \%$.

The Table 5 shows the total individual time of each of the 5 observations, which are used to calculate the determination of the number of cycles to be timed.

Table 5: Total individual time of each of the 5 observations

\begin{tabular}{c|c|c}
\hline Observation & $\begin{array}{c}\text { Individual readings in } \\
\text { seconds }(\mathbf{X})\end{array}$ & $\begin{array}{c}\text { Quadratic of individual readings } \\
\left(\mathbf{X}^{\mathbf{2}}\right)\end{array}$ \\
\hline 1 & 1230 & 1521.900 \\
\hline 2 & 1543 & 2380.849 \\
\hline 3 & 1256 & 1577.536 \\
\hline 4 & 1801 & 3243.601 \\
\hline 5 & 1879 & 3530.641 \\
\hline \multicolumn{2}{|c|}{$\Sigma x=7709$} & $\Sigma x^{2}=11984527$ \\
\hline \multicolumn{2}{|c|}{ Source: Prepared by the author with research data }
\end{tabular}

For the calculation of the determination of the number of cycles to be timed, was used the Equation 1, in which the result obtained was approximately 2 observations.

Given the presented data, it is verified that this result reached the specifications since the number of observations (5) was more significant than the result of $\mathrm{N}^{\prime}$ and therefore it is valid and possible to be used as "timed time" of the activity, with 95\% accuracy.

\subsubsection{Evaluation of the operator's pace and determination of normal}

The evaluation of the rhythm is one of the most individual phases of the study and therefore is also more complicated since it depends very much on the analyst's look because the analyst has to judge the speed of the operator while doing the study and observations. In the determination of the rhythm of the manicure, based on Table 1, was considered to be super-skilled (A2 - increase of $13 \%$ in the rhythm) and presented a good effort (C2 - increase of $2 \%$ in the rhythm). The condition of the work environment was considered as being average ( $D$ - 0.00), a fact that did not generate increase or decrease to the rhythm of the manicure, and the consistency of 
INDEPENDENT JOURNAL OF MANAGEMENT \& PRODUCTION (IJM\&P)

http://www.ijmp.jor.br

v. 10, n. 2, March - April 2019

ISSN: 2236-269X

DOI: 10.14807/ijmp.v10i2.842

the movements was considered regular ( $E$ - decrease of $2 \%$ to the rhythm). Thus, by means of Equation 2, a rhythm of $113 \%$ was obtained.

After determining the rhythm of the manicure and considering that the time selected for operation is $\mathbf{1 5 6 3 . 5}$ seconds, the determination of the normal time was made, by means of Equation 3, obtaining a time of 1766.755 seconds or approximately 29 minutes and 27 seconds.

It is important to point out that this value represents the time that a qualified and trained operator, in this case, studied refers to the manicure, working with regular rhythm, that would take to carry out a cycle of this operation, that is to carry out all the steps of the processes (sanding, cutting, trimming, enameling, etc.) that one has to perform the service of arranging the fingernail. Therefore, it is concluded that it does not deal with the standard time of this activity since tolerances must still be supplemented. Therefore, the next topic will address the determination of tolerances.

\subsubsection{Determination of tolerances and standard time}

As mentioned, regular time cannot be considered as standard time, because for an operation there must be some tolerance, since in any activity there are interruptions, either for rest or even to meet personal needs or waits. Thus, through the on-site observations and perception of the answers obtained through the semistructured interviews with the person in charge of the operation studied, the concessions of personal tolerance and fatigue were defined.

With regard to personal tolerance, the worker attends to his special needs like, to go to the bathroom and to drink water, sometimes during its operations. The service is performed in a location with controlled ambient temperature, although with little natural air circulation, which favors such tolerance. However, as there is a pause between one service and another, this pause only occurs in the latter case, in this sense, a percentage of $4 \%$ was assigned to their care.

In relation to the tolerance for fatigue, to date, there is no satisfactory way to measure fatigue. In this way, the favorable conditions of tolerance for fatigue, which are: the work done in a chair of dimensions disproportionate to the body volume, were analyzed by means of the Visual Observations and monitoring of the services and discussed with the one responsible for the activity, there is a need of constant 
INDEPENDENT JOURNAL OF MANAGEMENT \& PRODUCTION (IJM\&P)

http://www.ijmp.jor.br

v. 10, n. 2, March - April 2019

ISSN: 2236-269X

DOI: 10.14807/ijmp.v10i2.842

movements to pick up the tools and utensils used during the service and notably the adaptation of the employee to the place where the client is positioned, since usually, the client chooses to execute two services simultaneously. Thus, a percentage of $16 \%$ was attributed to fatigue tolerances. Therefore, the tolerance to operate the manicure service is $20 \%$.

Starting of the value of the normal time and the tolerance was calculated, by means of Equation 4, the standard time of the operation $(2120,106$ seconds or alternatively, approximately 36 minutes). In this sense, it can be concluded that using the chronoanalysis tool, the default time for the chosen operation is approximately 36 minutes, what does it mean to say this is the period required to provide a unit of the manicure service, taking into account the operator's ability, efforts, conditions and consistency, physical environment, materials, and equipment analyzed.

\section{PRESENTATION OF ANALYSIS AND SUGGESTIONS FOR IMPROVEMENT}

Given the context presented, it was observed that in the case study, performed in the beauty salon in question, specifically in the manicure services were discussed several difficulties faced by the service provider in the development of their task. Most of the difficulties are directly related to the inherent characteristics of the service performed, which the client interacts with the production process, that is, the client's attributes interfere with the service development, for example, the client's restlessness and nervousness in the process of utilisation can cause unwanted cuts on the cuticles as well as excess movements during the enameling step can generate imperfections in the paint and lead to the repetition of the entire process generating lots of time and material.

Another factor perceived during the analysis is the need for site changes during the execution of the task, which in turn generates a flow during service development, which requires an adaptation of the operator without taking into account the best posture to carry out the work. Thus, after the analysis of the service delivery process and from the study of times and methods, some proposals for improvement were made, aiming at increasing productivity and optimizing the workforce. Here are the suggestions:

\subsection{Use of the manicure kit:}


INDEPENDENT JOURNAL OF MANAGEMENT \& PRODUCTION (IJM\&P)

http://www.ijmp.jor.br

v. 10, n. 2, March - April 2019

ISSN: 2236-269X

DOI: 10.14807/ijmp.v10i2.842

This kit is a set of materials prepared in advance and one in a single location to avoid some movements during the process, which generate both physical discomfort and time losses. (\$ 0.4 cents), a portion of approximately $80 \mathrm{ml}$ of emollient moisturizer inserted without umbrella interior (0.8 cents), a mini nail file (\$ 0.8 cents) a wooden toothpick (\$0.6 cents) cotton (\$0.5 cents), acetone (\$0.10 cents), and a sterilized sterilizer for each kit. The set of materials and equipment would have an average cost of US 0.50 cents if it were set up by the operator itself during vacant hours and about $\$ 1.00$ for ready-made purchases. In this sense, an adoption of the practice responding by decreasing ten steps of the process, including seven movements and 3 actions within the flowchart. Representing a gain in time and movements, in addition to demonstrating indirectly to the company's customers regarding hygienic and sanitary aspects.

\subsection{Ergonomic adaptation of the service provider:}

This suggestion of better adapting the accommodations of the operator's work was based on the principles of economy of motion cited by Barnes, of which there is the guidance that when designing a work method in which the task must be organized so that operator perform the task in the shortest possible time, with greater ease and satisfaction; use the smallest number of body members and perform as few movements as possible, as well as minimize the length of your movements as well as energy and physiological strain wear. These movementsaving principles were associated with the task during the process of observation of the development of the same and are divided into three fields:

- The use of the human body - the anthropometric standards of the person in charge of the task require that it has an Effort higher than usual to perform the movements necessary to perform the task because the posture induces fatigue, discomfort, and future correlated diseases. According to Barnes (1977), the movements that are short, parabolic and simultaneous, run in opposite and symmetrical directions and cause less operator energy expenditure, are long, lateral, punctual, in the same direction and asymmetrical and require a substantial and structure involvement bone of the spine and arms; 
- Workplace layout - the seat used in operation has measures that are visibly inappropriate for the anthropometric standard of the operator, and the area of a disposition of the necessary material is also not located in an adequate way which contributes to the exercise of harmful movements that contribute to fatigue because they require more energy expenditure;

- Design of tools and equipment - this principle shows that hands must be relieved of any work that can be performed more conveniently by another device, this time, due to the characteristics of the service under analysis, it was not considered.

Therefore, the present suggestion consists of the design and manufacture of an armchair in the appropriate dimensions and furniture that has the possibility of locomotion and presents a structure of arranging the materials and equipment to facilitate the movements necessary to perform the service.

\section{FINAL CONSIDERATIONS}

In view of the above, the use of the tools of the time study (cronoanalysis) and the study of methods (flowchart), which was originally developed for application in manufacturing processes, was applied in a service delivery process and allowed through Observations and analyzes perceive results that enabled the achievement of the objectives proposed in this research. In this sense, this article sought to address the study of times and methods in an essential process of a beauty salon, the manicure service, which is usually performed by a professional qualified for this purpose, who acts independently of the other processes, is usually outsourced and receives fixed payments plus a commission for each service performed.

From this perspective, this study is relevant because has sought to optimize both the waiting time and the time of execution of the manicure service offered by a beauty salon, determining by means of a standard time, the need to have a greater agility in the provision of this service.

So, the Method Engineering that deals of registry, analysis and the aid in the improvement of the processes, contributed by showing that your application can facilitate the implementation of better and easier methods to perform a task. However, it is necessary to study all the details related to the work, in the search for particular information about a certain task in the process. 
INDEPENDENT JOURNAL OF MANAGEMENT \& PRODUCTION (IJM\&P)

http://www.ijmp.jor.br

v. 10, n. 2, March - April 2019

ISSN: 2236-269X

DOI: 10.14807/ijmp.v10i2.842

Therefore, in this case, as the most requested service in the salon, particular attention should be given to expanding the knowledge of the activity about times and methods and to provide company managers with greater control of the time elapsed in the provision of the service, which was a result obtained through the meeting of the standard time, as well as in the monitoring of productivity. The conclusion of the studies applied in the present research was to contribute to a better management of the methods adopted to perform the task and in turn to perceive the level of the degree of productivity operator.

It was also possible to verify ways to optimize the operator satisfaction in the task performance through Observations of the execution of the activity and the proposal of improvement suggestions regarding the use of the kits and the ergonomic adaptations. The present research has contributed effects to add value to employee and employer and consequently to influence the degree of profitability of the organization through the studies of times and methods of execution of a service and to favor a positive organizational climate by suggesting investments in improvements for employees, while such improvements will be reverted to earnings for the company.

\section{REFERENCES}

ANIS, G. C. (2010) A Importância dos estudos de tempos e métodos para controle da produtividade e qualidade. September. Acessed 20 March 2017. https://www.polimeroseprocessos.com/imagens/tempometodos.pdf.

BARNES, R. M. (1977) Estudo de movimentos e de tempos: projeto e medida do trabalho. 6 ed. São Paulo: Blucher.

BORBA, M. et.al. (2008) Comparação dos métodos de análise de tempos prédeterminados MTM-A1 e MTMUAS: um estudo de caso junto a uma linha de montagem de telefones. In: XV SIMPÓSIO DE ENGENHARIA DE PRODUÇÃO SIMPEP. Proceedings... Bauru/SP, November, 10-12.

CONTADOR, J. C. (2010) Gestão de operações: A engenharia de produção a serviço da modernização da empresa. 3 ed. São Paulo: Blucher.

CORRÊA, H. L.; GIANESI, I. G. N. (2012) Administração estratégica de serviços: operações para satisfação dos clientes. 1 ed. São Paulo: Atlas.

FELIPPE, A. D., et al. M. (2012) Análise descritiva do estudo de tempos e métodos: uma aplicação no setor de embaladeira têxtil. In: IX SIMPÓSIO DE EXCELÊNCIA EM GESTÃ̃ - SEGET. Proceedings... Rio de Janeiro/RJ, October, 24-26.

FIGUEIREDO, F. J. S.; OLIVEIRA, T. R. C.; SANTOS, M. B. P. A. (2011) Estudo de tempos em uma indústria e comércio de calçados e injetados Ltda. In: XXXI 
INDEPENDENT JOURNAL OF MANAGEMENT \& PRODUCTION (IJM\&P)

http://www.ijmp.jor.br

v. 10, n. 2, March - April 2019

ISSN: 2236-269X

DOI: 10.14807/ijmp.v10i2.842

ENCONTRO NACIONAL DE ENGENHARIA DE PRODUÇÃO - ENEGEP.

Proceedings...Belo Horizonte/MG, October, 4-7.

FITZSIMMONS, J. A.; FITZSIMMONS, M. J. (2010) Administração de Serviços: Operações, Estratégia e Tecnologia da Informação. 1 ed. Porto Alegre: Bookman.

JURAN, J. M.; GRYNA, F. M. (1993) Controle da Qualidade. 4 ed. São Paulo: Makron, McGrawHill.

LOVELOCK, C.; WIRTZ, J.; HEMZO, M. A. (2011) Marketing de serviços:

Pessoas, Tecnologia, Estratégia. 7 ed. São Paulo: Pearson.

MARTINS, P. G.; LAUGENI, F. P. (2005) Administração da produção. 2 ed. São Paulo: Saraiva.

MIAO, et al. (2012) MobiHealthcare System: Body Sensor Network Based M-Health System for Healthcare Application. E-Health Telecommunication Systems and Networks, v. 1, n.1, 12-18. http://dx.doi.org/10.4236/etsn.2012.11003

NORONHA, A. P. L.; OLIVEIRA, S. B.; LEITE, M. S. A. (2006) Aplicação do custeio baseado em atividade (ABC) aos serviços prestados por um salão de beleza. In: XXVI Encontro Nacional de Engenharia de Produção - ENEGEP. Proceedings... Fortaleza/CE, October, 9-11.

PEINADO, J.; GRAEML, R. A. (2007) Administração da produção. 1 ed. Curitiba: Unicenp.

POLLACK, B. L. (2008) The nature of the service quality and satisfaction relationship: Empirical evidence for the existence of satisfiers and dissatisfiers.

Managing Service Quality, v. 18, n. 6, 537-558.

http://dx.doi.org/10.1108/09604520810920059

RIBEIRO, J. L. D.; THIESEN, J. P. K.; TINOCO, M. A. C. (2013) Determinantes da satisfação e atributos da qualidade em serviços de salão de beleza. Produção, v. 23, n. 3, 609-624. http://dx.doi.org/10.1590/S0103-65132012005000080

SANTOS, R. L. S.; BARRETO, E. G. L.; MENEZES, V. L. (2011) Análise e proposta de melhorias de atividades em uma empresa de serviços a partir da utilização dos recursos esquemáticos. In: XXXI Encontro Nacional de Engenharia de Produção ENEGEP. Proceedings... Belo Horizonte/MG, October, 4-7.

SEBRAE - Service to Support Micro and Small Enterprises (2016). Práticas de empreendedorismo para salões de beleza no Brasil. Available:

http://www.bibliotecas.sebrae.com.br/chronus/ARQUIVOS_CHRONUS/bds/bds.nsf/4 602d82927d00015cd3a739fc78b01ae/\$File/7384.pdf. Access: 13/03/2017.

SLACK, N.; CHAMBERS, S.; JOHNSTON, R. (2009) Administração da produção. 3 ed. São Paulo: Atlas.

SOUTO, M. S. M. L. (2004) Engenharia de Métodos. Curso de especialização em Engenharia de Produção. Universidade Federal da Paraíba, PPGEP.

TALLURI, S.; MYUNG K. K.; TOBIAS S. (2013) The Relationship between operating efficiency and service quality: are they compatible?" International Journal of

Production Research, v. 51, n. 8, 2548-67.

https://doi.org/10.1080/00207543.2012.737946

TARDIN, M. G. et al. (2013) Aplicação de conceitos de engenharia de métodos em uma panificadora: um estudo de caso na panificadora Monza. In: XXXI Encontro 
Nacional de Engenharia de Produção - ENEGEP. Proceedings... Salvador/BA, October, 8-11.

TOLEDO JÚNIOR, I.F.B. (2004) Tempos \& Métodos. 8 ed. Mogi das Cruzes SP: Escola Editora.

VIEIRA, R. R., et al. (2016). Estudo de tempos e métodos no processo produtivo de uma panificadora localizada em Mossoró/RN. Gestão e Sociedade, v. 9, n. 23, 977999. https://doi.org/10.21171/ges.v9i23.2029

WEINSWIG, D. (2016) Fung Global Retail \& Technology. The Beauty Market in Brazil. 